\title{
E449X Mutation in the Thyroid Hormone Receptor $\beta$ Associated with Autoimmune Thyroid Disease and Severe Neuropsychomotor Involvement
}

\begin{abstract}
Objective: To report the clinical and molecular aspects of a patient with a diagnosis of Resistance to Thyroid Hormone (RTH) harboring the E449X mutation associated with autoimmune thyroid disease and severe neuropsychomotor retardation. Methods: We present a case report including clinical and laboratory findings, and molecular analysis of a Brazilian patient with RTH. Results: A 23-year old male presented hyperactivity disorder, attention deficit, delayed neuropsychomotor development, and goiter. Since the age of 1 year and 8 months, his mother had sought medical care for her son for the investigation of delayed neuropsychomotor development associated with irritability, aggressiveness, recurrent headache, profuse sudoresis, intermittent diarrhea, polyphagia, goiter, and low weight. Laboratory tests revealed normal $\mathrm{TSH}$, increased $\mathrm{T}_{3} \mathrm{~T}_{4^{\prime}}$ antithyroglobulin and antimicrosomal antibody titers. Increasing doses of levothyroxine were prescribed, reaching $200 \mu \mathrm{g} /$ day, without significant changes in his clinical-laboratory picture. Increasing doses of tiratricol were introduced, with a clear clinical improvement of aggressiveness, hyperactivity, tremor of the extremities, and greater weight gain. Molecular study revealed a nonsense mutation in exon 10, in which a substitution of a guanine to tyrosine in nucleotide 1345 (codon 449) generates the stop codon TAA, confirming the diagnosis of RTH. Conclusion: This patient has severe neuropsychomotor retardation not observed in a single previous report with the same mutation. This may reflect the lack of a genotype-phenotype correlation in affected cases with this syndrome, suggesting that genetic variability of factors other than $\beta$ receptor of thyroid hormone (TR $\beta$ ) might modulate the phenotype of RTH. (Arq Bras Endocrinol Metab 2008; 52/8:1203-1210)
\end{abstract}

Keywords: Resistance to Thyroid Hormone; TR $\beta$ gene; E449X Mutation; Autoimmune; Thyroid Disease; Retarded Neuropsychomotor Development

\section{RESUMO}

Mutação E449X no Receptor $\beta$ do Hormônio Tireoidiano Associada com Doença Tireoidiana Auto-Imune e Retardo Neuropscicomotor Grave.

Objetivos: Descrever aspectos clínicos e moleculares de um paciente com resistência ao hormônio tireoidiano (RHT) portador da mutação E449X associada a doença tireoideana auto-imune e retardo neuropscicomotor grave. Métodos: Relatamos um caso incluindo achados clínicos, laboratoriais e análise molecular de um paciente brasileiro com RHT. Resultados: Paciente masculino, 23 anos de idade, apresentou-se com distúrbio de hiperatividade, déficit de atenção, retardo no desenvolvimento neuropsicomotor e bócio. Desde 1 ano e 8 meses de idade, sua mãe procurou assistência médica para investigação do retardo do desenvolvimento neuropsicomotor associado com irritabilidade, agressividade, cefaléia recorrente, sudorese profusa, diarréia intermitente, polifagia, bócio e perda de peso. Avaliação laboratorial evidenciou TSH normal e aumento do T3, T4 e anticorpos antimicrossomal e clinical case report

\author{
Maria Helane Costa Gurgel \\ RENAN M. MONTENEGRO JUNIOR \\ Rejane Araujo Magalhaes \\ Grayce Ellen da C. Paiva Lima \\ Renan Magalhäes Montenegro \\ Patricia Kunzle Ribeiro MagalHÃes \\ lea Maria Zanini Maciel
}

Serviço de Endocrinologia e Diabetes do Hospital Universitário Walter Cantídio, Universidade Federal do Ceará (MHCG, RMMJ, RAM, GECPL, RMM), Fortaleza,

CE, Brasil; Divisão de

Endocrinologia do

Departamento de Clinica Médica da Faculdade de Medicina de Ribeirão Preto, Universidade de São Paulo (PKRM, LMZM), Ribeirão Preto, SP, Brasil.

Received in 29/7/2008

Accepted in 28/9/2008 
antitireoglobulina. Doses crescentes de levotiroxina foram prescritas, máximo de $200 \mu \mathrm{g} / \mathrm{dia}$, sem significativas alterações em seu quadro clínico-laboratorial. Doses crescentes de tiratricol foram introduzidas com melhora clínica evidente da agressividade, da hiperatividade, do tremor de extremidades e maior ganho de peso. O estudo molecular revelou uma mutação nonsense no éxon 10, no qual a substituição da guanina pela tirosina no nucleotídeo 1345 (códon 449) gerou um stop códon TAA, confirmando o diagnóstico da RHT. Conclusão: Este paciente tem um grave retardo neuropiscomotor não observado em um relato único anterior com a mesma mutação. Isto pode refletir a falta de relação genotipo-fenótipo nos casos afetados com esta síndrome sugerindo que a variabilidade genética de outros fatores, além do receptor do hormônio tireoidiano (HT), possa modular o fenótipo da RHT. (Arq Bras Endocrinol Metab 2008; 52/8:1203-1210)

Descritores: Resistência ao hormônio tireoidiano; gene TR $\beta$; Mutação E449X; Doença tireoideana auto-imune; Desenvolvimento neuropsicomotor retardado

\section{INTRODUCTION}

T he resistance to thyroid hormone (RTH) syndrome was first described by Samuel Refetoff and cols., in 1967 (1). Several cases were later reported, most of them involving clinically euthyroid patients, whereas other involved patients with signs and symptoms of hypothyroidism and/or thyrotoxicosis. These were associated with biochemical changes such as elevated thyroid hormone (TH) levels - $\mathrm{T}_{3}$ and $\mathrm{T}_{4}$ and inappropriately normal or elevated thyroid stimulating hormone (TSH) levels, demonstrating tissue insensitivity to the action of these hormones. The most common pattern of inheritance is autosomal dominant, but there are also reports of a recessive pattern and of sporadic and de novo cases. The disease has been more frequently associated with heterozygous mutations of the $\beta$ receptor of TH (TR $\beta)$ $(2,3)$. More than 1000 cases belonging to 344 different families have been reported thus far, involving approximately 124 mutations, with missense mutations being more frequent (4). There are no pathognomonic clinical findings for RTH because, due to the variable resistance of different tissues, symptoms of hypothyroidism such as inadequate weight-height development, delayed bone age and mental retardation may coexist with symptoms of hyperthyroidism such as attention deficit, tachycardia and hyperactivity (2). Several studies have discussed whether the severity of the clinical manifestations of patients with RTH is correlated with the degree of functional impairment of the mutated receptor (5).

There is no currently specific treatment for the correction of the primary defect of RTH (2). In most of the cases described, untreated patients maintain a normal metabolic status, whereas some patients with more marked peripheral resistance require supraphysiological doses of TH (2).

Although more than 1000 cases of RTH have been reported in the world literature, coexistence of autoimmune thyroid disease has been seldom reported. Sato and cols. (6) reported that patients with RTH in general have no antithyroglobulin or antithyroperoxidase antibodies, excepting rare cases in which there is coexistence of chronic autoimmune thyroiditis.

We report here a 23-year-old male patient with autoimmune thyroid disease and RTH due to a nonsense mutation, in which a substitution of a guanine to tyrosine in nucleotide 1345 (codon 449) generated the stop codon TAA. The patient presented severe neuropsychomotor manifestations, a clinical picture that has not been previously reported in association with this mutation (7).

\section{SUBJECTS AND METHODOS}

\section{Case report}

A 23-year old mulatto male born to non-consanguineous parents, according to his mother, presented hyperactivity disorder, attention deficit, delayed neuropsychomotor development, and goiter. Since the age of 1 year and 8 months, the mother had sought medical care for her son for the investigation of delayed neuropsychomotor development associated with irritability, aggressiveness, recurrent headache, profuse sudoresis, intermittent diarrhea, poly- 
phagia, increased cervical volume, and low weight. The patient had been born at term by normal delivery with cyanosis, weighing $2300 \mathrm{~g}$ and measuring $47 \mathrm{~cm}$. However, he had not needed intensive supportive care and had been discharged from the hospital within 48 hours. No neonatal screening test was performed. He presented delayed neuropsychomotor development, sitting up at 1 year, walking at 3 years and speaking at 4 years. The mother denied prenatal problems or a similar history among family members.

At his first evaluation at 5 years of age, the patient presented hyperactivity and irritability, weight and height in the 3rd and 50th percentiles, respectively, diffuse increase in thyroid volume (approximately 2 to 3 times) without exophthalmia, and tachycardia at rest (heart rate of $120 \mathrm{bpm}$ ). Psychodiagnostic evaluation revealed a high degree of impairment of cognitive aptitudes and of social-motor language associated with a low level of visuomotor coordination. Laboratory tests at 5 years of age revealed total T3 $>580 \mathrm{ng} /$ $\mathrm{dl}$ (reference value: 90-200 ng/dl), total T4 $23.2 \mu \mathrm{g} /$ $\mathrm{dl}$ (reference value: $4.5-12.5 \mu \mathrm{g} / \mathrm{dl}$ ), and TSH:3.5 $\mu \mathrm{IU} / \mathrm{ml}$ (reference value: 0.3-3.0 $\mu \mathrm{IU} / \mathrm{ml}$ ), antithyroglobulin antibody titers: $1: 400$, and antimicrosomal antibody titers of: 1:25,600.

Methimazole (Tapazol®) up to $30 \mathrm{mg} /$ day and propranolol $(30 \mathrm{mg} /$ day $)$ were started by the oral route without a significant clinical improvement, except for reduction of tremor and irritability, with persistence of weight deficit, hyperkinesia and emotional lability, tachycardia and goiter. Laboratory evaluations during the subsequent six years of treatment revealed persistently elevated levels of total T3 and T4 and inappropriately normal TSH (Table 1). Thyroid scintigraphy with $99 \mathrm{mTc}$--pertechnetate demonstrated a marked increase in gland volume, especially the right lobe, with globally increased uptake (79\% within 24 hours) and slightly heterogeneous distribution. At the age of 12 , he was submitted to radioiodine therapy with $15 \mathrm{mCi}$ of 131I. In view of no resolution of symptoms and

Table 1. Laboratory profile of a patient with thyroid hormone resistance without and during treatment with methimazole (Tapazol(B) and after the administration of ${ }^{131}$ lodine followed by replacement with levothyroxine and tiratricol (Triac $(B)$.

\begin{tabular}{|c|c|c|c|c|}
\hline $\begin{array}{l}\text { Patient age } \\
\text { (years old) }\end{array}$ & Treatment & $T_{3}(n g / d L)$ & $\begin{array}{c}\mathrm{T}_{4}(\mu \mathrm{g} / \mathrm{dL}) / \\
{ }^{*} \text { Freet }_{4}(\mathrm{ng} / \mathrm{dL})\end{array}$ & TSH $(\mu \mathrm{lU} / \mathrm{mL})$ \\
\hline 5 & None & 580.0 & 23.2 & 3.5 \\
\hline 5.3 & TPZ - 30mg & $>800.0$ & $>30.0$ & 4.5 \\
\hline 6 & TPZ - 30mg & 84.0 & 36.0 & 1.3 \\
\hline 12 & \multicolumn{4}{|c|}{ Administration of ${ }^{131}$ lodine } \\
\hline 14 & $\mathrm{LT}_{4}(150 \mu \mathrm{g})$ & - & $2.5^{\star}$ & $>50.0$ \\
\hline 15 & $\mathrm{LT}_{4}(150 \mu \mathrm{g})$ & - & $1.69^{*}$ & 134.0 \\
\hline 16 & $\mathrm{LT}_{4}(150 \mu \mathrm{g})$ & - & $1.23^{*}$ & $>60.0$ \\
\hline 17 & $\mathrm{LT}_{4}(200 \mu \mathrm{g})$ & - & $1.64^{*}$ & $>60.0$ \\
\hline 18 & $\mathrm{LT}_{4}(200 \mu \mathrm{g})$ & - & $1.94^{*}$ & 69.4 \\
\hline 19 & $\mathrm{LT}_{4}(100 \mu \mathrm{g})+\operatorname{Triac} ®(75 \mu \mathrm{g} / \mathrm{d})$ & 168.9 & $1.5^{\star}$ & 56.1 \\
\hline 20 & $\mathrm{LT}_{4}(100 \mu \mathrm{g})$ & 92.8 & $1.2^{*}$ & 74.3 \\
\hline 21 & $\mathrm{LT}_{4}(200 \mu \mathrm{g})+\operatorname{Triac} \AA(50 \mu \mathrm{g} / \mathrm{d})$ & 151.8 & $3.5^{\star}$ & 45.0 \\
\hline 22 & $\mathrm{LT}_{4}(150 \mu \mathrm{g})+\operatorname{Triac} \AA(100 \mu \mathrm{g} / \mathrm{d})$ & 130.0 & $1.7^{*}$ & 65.5 \\
\hline 23 & $\mathrm{LT}_{4}(200 \mu \mathrm{g})+\operatorname{Triac}{ }^{\circledR}(150 \mu \mathrm{g} / \mathrm{d})$ & 150.5 & $2.2^{*}$ & $>100.0$ \\
\hline 23.4 & $\mathrm{LT}_{4}(150 \mu \mathrm{g})+\operatorname{Triac} \AA(200 \mu \mathrm{g} / \mathrm{d})$ & 158.9 & $3.05^{\star}$ & $>40.0$ \\
\hline
\end{tabular}

TPZ = Tapazol $\Theta$ (methimazole); Triac ${ }^{\circledR}$ (tiratricol); LT4 (levothyroxine); - : not available; Reference Values: $\mathrm{T}_{3}: 90-200 \mathrm{ng} / \mathrm{dL} ; \mathrm{T}_{4}: 4.5-12.5 \mathrm{\mu g} / \mathrm{dL} ;$ Free $\mathrm{T}_{4}: 0.71-1.85 \mathrm{ng} / \mathrm{dL} ; \mathrm{TSH}:$ $0.3-3.0 \mu \mathrm{lU} / \mathrm{mL}$ 
signs, the patient was investigated for the exclusion of a TSH-secreting pituitary tumor (thyrotrophinoma). The TSH response to intravenous TRH administration was higher than $40 \mu \mathrm{IU} / \mathrm{ml}$ at all time points. The level of the $\alpha$ subunit of TSH was $0.47 \mathrm{mIU} / \mathrm{ml}(\mathrm{VR}<0.8$ $\mathrm{mIU} / \mathrm{ml}$ ). Futhermore, the evaluation of the hypotalhalamic-pituitary axis conducted with magnetic resonance imaging (MRI) didn't reveal any abnormality.

Increasing doses of levothyroxine were prescribed, reaching $200 \mu \mathrm{g} /$ day, without significant changes in the clinical-laboratory picture of the patient. Increasing doses of tiratricol (Triac ${ }^{\circledR} 50,75,100,150,200 \mu \mathrm{g} /$ day) were introduced (Table 1), an option that also did not result in TSH suppression but induced a clear clinical improvement of aggressiveness, hyperactivity, tremor of the extremities, and greater weight gain $(8,9)$. At present he is regularly taking $200 \mu \mathrm{g} /$ day tiratricol and $150 \mu \mathrm{g} /$ day levothyroxine, no longer presenting signs or symptoms of hyper- or hypothyroidism, and his heart rate is $70 \mathrm{bpm}$. His height is $163.5 \mathrm{~cm}(\mathrm{SD}=$ -0.9 ), his weight is $49.5 \mathrm{~kg}$ and his pubertal development is normal (G5 P5). He attends a special school for children with severe cognitive deficit. He cannot read or write but is able to execute domestic tasks.

A molecular study of this patient was recently performed by genomic extraction of peripheral blood DNA using a previously described method (3). The study revealed a nonsense mutation in exon 10 , in which a substitution of a guanine to tyrosine in nucleotide 1345 (codon 449) generates the stop codon TAA, confirming the diagnosis of RTH (Figure 1).
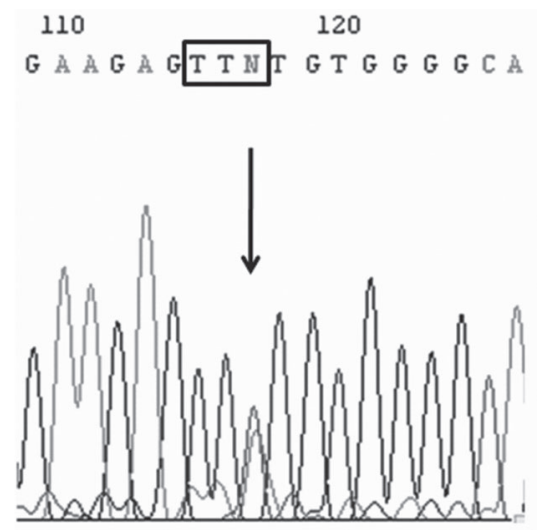

Figure 1. Representative (anti-sense) chromatogram of exon 10 of gene $\beta$ of the thyroid hormone receptor in a patient with resistance to thyroid hormone, showing the c.1345G $>T$ (p.E449X) mutation in heterozygosis. The arrow indicates the position of the mutation.

\section{DISCUSSION}

We report here a Brazilian patient with severe neuropsychomotor retardation and RTH due to the c. $1345 \mathrm{G}>\mathrm{T}$ mutation. In Brazil, Furlanetto and cols. (10) made the first report concerning the genetic study of the TR $\beta$. Recently, Magalhães and cols. (3) described the genotypic analysis of four unrelated kindreds from the Ribeirão Preto (SP) region, representing the largest Brazilian series published.

We report a patient who had been presenting clinical characteristics attributable to RTH since early infancy. Low birth weight as well as delayed bone maturation from the prenatal period to adult life are due to the reduced affinity of TH for the ligand domain of TR $\beta$, mimicking a state of hypothyroidism (2). Up to $30 \%$ of children with RTH have low weight for their age and very low weight for height (3), as was observed in the present patient, whose weight and height were in the 3rd and 50th percentile, respectively. Attention deficit and hyperactivity, the major symptoms that led the present patient to seek medical care, have been explained by a possible action of TH on the development of central monoaminergic pathways (11). Tachycardia and goiter, also observed in the present case, are common findings frequently acting as confounding diagnostic factors since they mimic the signs and symptoms of thyrotoxicosis $(2,3)$. Varied degrees of attention deficit or learning disorders may be detected in up to $50 \%$ of cases. However, severe neuropsychomotor retardation, as observed in the present patient, is uncommon, being detected in approximately $4-16 \%$ of the cases (12). To the best of our knowledge the present case is the first description of E449X nonsense mutation with this phenotype described here. Miyoshi and cols. (13) identified three truncated TR $\beta 1$ s with 11 (F451X), 13 (E449X) and 16 (C446X) amino acids deletions within this domain in patients with RTH but only the patients harboring a C-terminal truncated receptor, F45IX and C446X, exhibited severe mental retardation. Phillips and cols (14) also described a patient with severe phenotype including severe mental retardation with a TR $\beta$ truncation mutant, R438Xfs. Transient expression study revealed that these mutants had negligible T3 binding and transcriptional activities (13).

The laboratory work-up described here corresponds to the characteristic pattern of RTH, i.e., an inappropriately normal TSH level and elevated free T4 and total T3 levels (12). As mentioned in previous studies 
(3), an erroneous diagnosis of thyrotoxicosis is not infrequent, as was initially the case for the patient reported here. The high thyroid iodine uptake described (79\% in $24 \mathrm{~h}$ ), associated with clinical signs and symptoms compatible with thyrotoxicosis, and frequently leads to erroneous treatment with antithyroid drugs and/or radioactive iodine.

Although it is an important differential diagnosis, the determination of subunit $\alpha$, associated with the absence of characteristic pituitary damage, excluded the possible presence of thyrotropinomas. The present patient had high antithyroid antibody titers (1:400 for antithyroglobulin antibodies and 1:25,600 for antimicrosomal antibodies), an infrequent finding in previous reports. Search for heterophilic antibodies was not performed, once the mutation E449X was found. Sato and cols. (6) reported that RTH is not associated with the presence of antithyroid antibodies except in rare cases in which autoimmune thyroiditis coexists. Gavin and cols. (15) raised the hypothesis that the chronic TSH elevation occurring in RTH syndrome may stimulate lymphocytes to produce antibodies against the $\mathrm{TH}$ receptor.

It has been previously demonstrated that, despite the excess $\mathrm{TH}$, most patients continue to be euthyroid, probably due to adequate compensation for the increase in endogenous $\mathrm{TH}$, with no need for treatment (2). However, some individuals have more resistant peripheral tissues, requiring supraphysiological doses of $\mathrm{TH}$ (2). Treatment of the present patient with tiratricol improved the symptoms of hyperactivity and attention deficit and reduced the goiter without an increase of thyromimetic effects on peripheral tissues, a fact that can be explained by a greater affinity of this drug for TR $\beta$.

The genetic study conducted on this patient identified a nonsense mutation in exon 10 , in which a substitution of a guanine to tyrosine in nucleotide 1345 (codon 449) generated the TAA stop codon and a truncated protein with 13 amino acids missing. There is only one previous report of this mutation, published by Taniyama and cols. (7) in 1996, affecting a eumetabolic 16-year-old Japanese boy with elevated TH levels and with a mild form of clinical involvement. In contrast, in the case reported here the patient presented severe neuropsychomotor impairment, reflecting a more severe spectrum of phenotypic expression. This fact confirms the variability of the phenotype associated with a specific genotype in RTH syndrome, supporting the absence of a clear correlation between the clinical severity of RTH and the degree of functional failure of $\operatorname{TR} \beta(5)$.

In conclusion, the present report describes a rare case of RTH with a nonsense mutation in exon 10, in which a substitution of a guanine to tyrosine in nucleotide 1345 (codon 449) generated the stop codon TAA. This mutation is associated with autoimmune thyroid disease and with severe neuropsychomotor involvement, a clinical picture not previously described in association with this genotype, suggesting once more the phenotypic diversity of patients with mutations in the $\operatorname{TR} \beta$ gene.

No potential conflict of interest relevant to this article was reported.

\section{REFERENCES}

1. Refetoff S, De Wind LT, Degroot LJ. Familial syndrome combining deaf-mutism, stuppled epiphyses, goiter and abnormally high PBI: possible target organ refractoriness to thyroid hormone. J Clin Endocr Metab. 1967;27:279-94.

2. Weiss RE, Refetoff S. Resistance to thyroid hormone. Rev Endocr Metab Disord. 2000;1:97-108.

3. Magalhães PKR, Rodrigues Dare GL, Rodrigues dos Santos $\mathrm{S}$, et al. Clinical features and genetic analysis of four Brazilian kindreds with resistance to thyroid hormone. Clin Endocrinol (Oxf). 2007;67:748-53.

4. Refetoff S, Dumitrescu AM Syndromes of reduced sensitivity to thyroid hormone: genetic defects in hormone receptors, cell transporters and deiodination. Best Pract Res Clin Endocrinol Metab. 2007;21:277-305.

5. Hayashi Y, Weiss RE, Sarne DH, Yen PM, Sunthornthepvarakul $\mathrm{T}$, Marcocci C, et al. Do clinical manifestations of resistance to thyroid hormone correlate with the functional alteration of the corresponding mutant thyroid hormone-beta receptors? J Clin Endocrinol Metab. 1995;80:3246-56.

6. Sato $\mathrm{H}$, Sakai $\mathrm{H}$ A family showing resistance to thyroid hormone associated with chronic thyroiditis and its clinical features: A case report. Endocr J. 2006;53:421-5.

7. Taniyama M, Kusano S, Miyoshi $Y$, Nakamura H, Kaihara M, Tobe T, et al. Mild resistance to thyroid hormone with a truncated thyroid hormone receptor beta. Exp Clin Endocrinol Diabetes. 1996;104:339-43.

8. Torre P, Bertoli M, Di Giovanni S, Scommegna S, Conte C, Novelli G, Cianfarani S. Endocrine and neuropsychological assessment in a child with a novel mutation of thyroid hormone receptor: Response to 12-month triidothyroacetic acid (TRIAC) therapy. J Endocrinol Invest. 2005;28:657-62.

9. Messier N, Laflamme L, Hamann G, Langlois MF. In vitro effects of Triac on resistance to thyroid hormone receptor mutants: potential basis for therapy. Mol Cell Endocrinol. 2001;174:59-69.

10. Furlanetto TW, Kopp P, Peccin S, Gu WX, Jameson JL. A novel mutation (M310L) in the thyroid hormone receptor beta causing resistance to thyroid hormone in a Brazilian kindred and a neonate. Mol Genet Metab. 2000;71:520-6. 
11. Ciaranello RD. Attention deficit-hyperactivity disorder and resistance to thyroid hormone--a new idea? N Engl J Med. 1993;328:1038-9.

12. Refetoff $\mathrm{S}$, Weiss RE, Usala SJ. The syndromes of resistance to thyroid hormone. Endocr Rev. 1993;14:348-99.

13. Miyoshi Y, Nakamura H, Tagami T, Sasaki S, Dorin RI, Taniyama M, Nakao K. Comparison of the functional properties of three different truncated thyroid hormone receptors identified in subjects with resistance to thyroid hormone. Mol Cell Endocrinol. 1998;137:169-76.

14. Phillips SA, Rotman-Pikielny PP, Lazar J, Ando S, Hauser P, Skarulis MC, et al. Extreme Thyroid Hormone Resistance in a
Patient with a Novel Truncated TR Mutant. J Clin Endocrinol Metab. 2001;86:5142-7.

15. Gavin C, Meggison H, Ooi TC. Proposing a causal link between thyroid hormone resistance and primary autoimmune hypothyroidism. Med Hypotheses. 2008;70:2014-8.

\section{Correspondence to:}

Renan Magalhaes Montenegro Junior

Av. Desembargador Moreira, 1640

70170-001 Fortaleza, CE, Brazil

E-mail: renanjr@ufc.br/renanmontenegrojr@terra.com.br 